\title{
Does Ethnicity Matters in Capital Structure Decision in Family Firms? Overview of Agency Theory
}

\author{
Noorhayati YUSOF ALI and Zuriyati AHMAD
}

Faculty of Business Management, Universiti Teknologi MARA, Malaysia

Correspondence should be addressed to: Noorhayati YUSOF ALI; noorhayatiy@uitm.edu.my

Received date:19 November 2020; Accepted date: 21 January 2021; Published date:4 May 2021

Academic Editor: R. H. Kuruppuge

Copyright @ 2021. Noorhayati YUSOF ALI and Zuriyati AHMAD. Distributed under Creative Commons Attribution 4.0 International CC-BY 4.0

\begin{abstract}
Drawing on the evidence indicating that prominent features of Asian companies are notably the concentrated ownership with extensive family ownership and dominance of controlling shareholders controlled by two main ethnic groups in Malaysia, namely the Chinese and the Malays, this study attempts to investigate the effect of ownership and ethnicity on the financing decisions of Malaysian family firms. This study employs literature on family businesses and explains the possible impact of family and business reciprocity coupled with the issue of ethnicity within a family firm that drives the uniqueness of the firm itself. It is believed that the special characters, such as strong family ties, undiversified family holdings, and the strong desire to hand over the company to subsequent successors as well as the higher concerns to maintain the family reputation tend to offer different incentive structures, at least in regards to the capital structure. The agency theory suggests that family companies have lower agency problems because the owner-manager interests tend to be more consensual, thus giving creditors greater confidence to lend. Although this study is qualitative in nature, it is unique, because it deals with the determinants of the capital structure that is almost not found in developed countries. This provides an alternative explanation for the financial variation and provides evidence on the universality of the capital structure theory.
\end{abstract}

Keywords: Family Firms, Ethnicity, Bumiputera, Leverage, Agency Theory.

\section{Introduction}

Since the scientific work by Modigliani and Miller (1958), the theory of capital structure has become an important topic of debate in many studies. Evidencing from that, many studies have sought to identify the determinants of firm's capital structure in various economic markets. These determinants include taxability, firm size, 
asset tangibility, growth opportunities and profitability. The more recent and deliberate literature strands focus on the impact of inhouse firm-specific features such as ownership structures on capital structure choices (Masdiah, Azizah \& Nur Atiqah, 2015; Lean, Ting \& Kweh, 2015)

Studies on the determinants of the capital structure focus on developed economies with mixed results. The impact of ownership structures on companies' financing decisions in emerging markets such as Malaysia has yet to be explored (Fan, Wei \& $\mathrm{Xu}, 2011)$. The majority of the companies listed in emerging markets are family owned. Claessen, Djankov and Lang (2000) found that almost 68 per cent of the sample of their Malaysian companies is family-run, and 28.3 percent of market capitalization is run by 15 families.

Given the prevalence of family businesses in Malaysia, it provides a significant platform to analytically propose how family ownership, in the realm of the agency theory, is related to financing decisions, specifically, the levels of leverage. Another area that was greatly left unexplored is the effect of ethnicity on the capital structure. One possible explanation why this area of study is not addressed in many previous studies is due to the absence of ethnic diversity in most of other countries. Nevertheless, in Malaysia, diverse ethnics who dominate firms' ownerships are prevalent. Therefore, this study aims to explore whether there is a possibility that family ownership and ethnicity have an impact on the firms' capital structure decisions.

\section{Ownership Structure}

Prior studies have grouped corporate ownership structures into two categories namely widely held and closely held firms. A major distinction between these two types of firms is that a widely held firm does not have any owners with substantial control rights. Meanwhile, a closely held firm is identified when its shares are owned by identifiable and "cohesive groups of insiders" (Claessens et al., 2000) that form the ultimate control (Abdul Rahman \&
Salim, 2009). These shareholders generally have long-lasting stable relationships with the company, and they are typically members of the company's founding families. Other forms of shareholders inclusive in this group are lending banks, governments or other small groups of companies that are linked through cross shareholding, pyramidal ownership structures and dual class shares (Claessens et al., 2000; Manos et al., 2007). Cross shareholding and pyramidal ownership structures are common strategies extensively used by dominant shareholders to effectively exercise their control over the firm with relatively less direct stakes in the cash- flow rights.

It is well documented in the literature that families are the most significant type of firms with concentrated ownerships that shape a pattern of ultimate owners (Anderson \& Reeb, 2003; Abdul Rahman et al., 2009). Corporate ownership structures in the UK and US are more diffused as compared to ownerships and control in Malaysian public corporations which are more concentrated and family dominant (Claessens et al., 2000). In Malaysia, family firms constitute for more than two-third of the total firms while the remaining is generally held by state or institutional investors or else categorized as widely held corporations (Driffield et al., 2007).

Previous research suggests that agency problems only exist in a firm with a dispersed ownership structure (Fama \& Jensen, 1983). They argue that the separation of ownership and control is more likely to occur in companies with dispersed ownership structures where shareholders have limited control over management activities. Therefore, the management will be more likely to practice more freedom in the use of companies' resources compared to companies that are managed by their owners. Consistent with this view, Jensen and Meckling (1976) and Fama and Jensen (1983) also agree that the issue of separation of ownership and control in the modern dispersed ownership corporations is the root of agency problems. In short, this view implies that agency problems will be minimized if the control of corporate wealth 
is concentrated in one or a few large shareholders.

Sharma (2004) suggests that research on family firms cannot be justified just because the existence of family owned companies has dominated most parts of the world. She suggests that the study on family firms needs to be more legitimatized by identifying unique features of family firms which make them different from other business organizations. Attributes of families, such as cohesive groups of insiders, strong family ties, and feelings of loyalty and kinship obligations have been highlighted as features that are distinctive to family firms (Miller \& Le Breton-Miller, 2005). It is expected that these unique features could benefit family firms to some extent.

Malaysia signifies insider ownerships and control structures with concentrated shareholding dominated by families (Claessens et al., 2000; Abdul Rahman et al., 2009). One of the possible explanations why Malaysian firms are predominantly owned and controlled by families, in part, is due to the poor legal system where the rights of minority shareholders are not well protected (Abdul Rahman et al., 2009). Consequently, non-family investors would not find businesses as an attractive investment when their rights are less protected. As such, the business is more conducive for a family shareholder base but less conducive for a diverse shareholder.

\section{Family Firms}

Masdiah et al. (2015) demonstrate that family businesses dominate many emerging economies including Malaysia. Although the ownership structure of firms in developed countries is rather diffused, the existence of family firms is still substantial (La Porta et al., 1999). Unlike family firms in developed countries which typically employ professional managers, family firms in emerging markets are largely managed by inherited family members (Fan et al., 2011). These studies also reveal that the ownership of family firms in the developed markets becomes dispersed more quickly after becoming public, while the ownership in emerging markets remains highly concentrated even long after going public.

Literature shows that there is a distinction between family and non- family firms. For example, Brenes et al. (2006) define family firms as firms that are dominantly owned and managed by a solitary root family. They further state that this family typically holds a significant proportion of equity stakes in the firms. Similarly, Driffield et al. (2007) find that in family firms, the management and ownership arerarely separated where firms' leadership and top management team members are largely comprised of a controlling owner and family members. The findings on Asian firms, as reported by Fan et al. (2012), also support the definition put forth by prior studies. Fan et al. (2012) further add that since the controlling owner and management boards are members of the same family, it is expected that their interests are more closely aligned, which leads to less agency conflicts.

An ambiguity exists on how practitioners (e.g. family business managers, consultants and fund providers) and researchers define family businesses (Chua et al., 1999). In an attempt to reconcile any conflict related to family firms, one must make a distinction amongst three fundamental elements that are ownership, control and management in defining family firms (Villalonga \& Amit, 2006). Although definitions vary, family firms would imply that family members own higher levels of equity in their firms, in which ownerships are symbolized (Fama \& Jensen, 1983). Family controlled firms are normally differentiated by ownership concentration as well as the existence of a family-related person called 'Cronyman' (Driffield, Mahambare \& Pal, 2007).

According to Miller and Le Breton-Miller (2005), family businesses promote stagnation, isolation, hereditary, cronyism, favoritism, disagreement, and nuisance leadership. However, they also suggest the unique characteristics of the governance system such as cohesiveness, strong family ties, and loyalty and kinship obligations exist in family business. These unique 
features may help develop competitive advantages in terms of efficient investment decisions which enable firms to achieve better performance and higher returns with low agency costs (Villalonga \& Amit, 2006; Maury, 2006). Further, the interrelationship between the family and business systems may offer some benefits such as low monitoring cost of management and better coherence in optimizing decision making.

Family firms have long been recognized as common organizational forms worldwide. For instance, a study on ownership structures, by La Porta et al. (1999) on large corporations in 27 wealthy economies, shows that relatively very few of these firms are widely held, but rather, these firms are usually controlled by families or governments. Manos et al. (2007) report similar findings in which family is the dominant form of firms' ownership in developing countries due to prevailing market imperfections and information problems. Family firms are also found to dominate most of the East Asian corporations and have accounted significant amount of corporate wealth in the region (Claessens et al., 2000). Malaysia, in particular, more than two-third of its companies comprise of family businesses. The contribution of family businesses towards the economic growth is substantial. Ngui (2002) reports that family firms in Malaysia essentially contribute more than 50 percent of the country's Gross Domestic Product (GDP).

Although family firms, as organizational forms, have received a great deal of attention in recent years, studies that focus on financing-related issues in the context of family firms are still limited, particularly in the emerging markets (Colot \& Croquet, 2009). In emerging markets, such as Malaysia, the contribution towards this area of research is significantly less in numbers because studies on family related issues are still new in the Malaysian setting (Amran \& Che Ahmad, 2009). Moreover, the contextual setting, as indicated by Fraser et al (2006), reveal that the Malaysian market comprises of many unique features (i.e., ethnicity, culture, political patronage etc.) that are left unexplored.
Sharma (2004, p. 9) states that "the intertwinement and reciprocal relationships between the family and business systems is being recognized as the key feature distinguishing this field of study from others". Additionally, the emphasis on the formation of unique resources (e.g. friend and family financing) and capabilities are also getting the attention of researchers in this field (Chrisman et al., 2003). The presence of unique features of the family such as parsimony and personalism form its own governance systems that allows family owners to make decisions in ways that are largely unavailable to firms with other governance structures (Carney, 2005). In sum, the preceding discussion of family firms suggests unique attributes of family firms which potentially give rise to competitive advantages that serve interesting research setting to further explore the field.

\section{Agency Problem in Family Firms}

Agency relationship is a contract whereby the principal(s) engage another person (agent) to perform services on the principal's behalf (Jensen \& Meckling, 1976). This contract also involves entrusting some decision making authority to the agent. Due to the incomplete contract between the principal(s) and the agent(s) and with the presence of residual control rights, the agent(s) may betray these rights to benefit his/their own welfare (Nwanji \& Howell, 2007). This betrayal contributes to the agency problem and it becomes a common issue of debate within companies. They also argue that managers who manage other people's money cannot be expected to monitor them with the same prudence as when they monitor their own.

Many prior studies often use the agency theory as one of the most important research frameworks to explain the unique phenomenon in a family business. For instance, Morck and Yeung (2003) justify with evidence that the level of agency problems vary between companies with dispersed ownerships and concentrated ownerships. Shleifer and Vishny (1997) argue that narrowly held companies are 
expected to have lower agency problems as a result of better matching between control and cash flow rights. Likewise, Morck and Yeung (2003) suggest that agency problems might be lower in less diffused ownerships such as those controlled by families. Therefore, the incentives of the controlling shareholder are more likely to favor the interests of other shareholders. They also reveal that much discussion of prior studies on ownership structure have shown the evidence that the presence of block shareholdings (e.g. family firms) can assist the board to improve the effectiveness of monitoring in mitigating agency conflicts. This issue of agency problems becomes more severe due to the significant phenomenon of the separation of ownership and control.

Fama and Jensen (1983) highlight that one major factor in determining the survival of any form of organizations is the control of agency problems. These problems emerge because setting and enforcing a contract among agents with conflicting interests is rather costly. Furthermore, Fama and Jensen (1983) show that agency problems which occur in a firm with a separation of ownership and control should be regulated by the firms' decision systems that separate between the management and control. Discussing the firms' value, Villalonga and Amit (2006) show that concentrated ownership should have a positive impact on the firm value because it can reduce the classical conflicts between owners and managers. Villalonga and Amit (2006) suggest that a greater insider ownership is associated with better corporate governance. This is because managers, who hold larger equity stake holding in the company, would prefer not to take actions that can reduce the value of their shares that can affect their wealth. This shows that agency problems are low in narrowly held companies such as those controlled by families.

Nevertheless, agency problems could still exist in family firms due to the conflict of interests between the controlling family and minority shareholders (Morck \& Yeung,
2003; Villalonga \& Amit, 2006). They argue that the coupling of ownership and control could result in expropriation activities by the controlling families when they represent their own interests which may not coincide with the interests of other shareholders in the firms. Expropriation activities by families have been found to affect the performance of the firms specifically when the families are able to extract wealth from the firms. Evidencing from literature, family controlled firms dominate the Malaysian listed firms substantially (Claessens et al., 2000). Malaysia has a unique corporate landscape resulting from its own historical background influenced by the cultures of various countries such as Britain that used to occupy Malaysia, and India and China that have had business practices in this nation (Eichenseher, 1995; Haniffa \& Cooke, 2002; Johnson \& Mitton, 2003; Abdul Rahman \& Salim, 2009). Hence, the Malaysian community is made up of different ethnics, religions, creeds, traditions and languages. These elements are expected to influence various aspects of businesses, at least with regards to the capital structure.

\section{Ethnicity, Culture and Firms}

As discussed in the previous section, Malaysia has a unique corporate landscape produced from its historical background that has evolved and influenced by the cultures of various countries such as Britain which once occupied Malaysia, and immigrants from India and China who brought their cultures and traditions attached in business practices (Eichenseher, 1995; Haniffa \& Cooke, 2002; Johnson \& Mitton, 2003; Abdul Rahman \& Salim, 2009). Therefore, the Malaysian society is formed from various ethnicities, religions, beliefs, traditions and languages. Furthermore, the practice of affirmative actions usually involves measures to increase the participation of less fortunate ethnic groups in a number of areas such as education, and business can also influence enterprise financing decisions such as capital structure decisions.

One of the problems that often arises in most research related to capital structure is due to

Noorhayati YUSOF ALI and Zuriyati AHMAD, Journal of Southeast Asian Research, DOI: $10.5171 / 2021.122227$ 
the failure to explore cultural factors (Haniffa \& Cooke, 2002; Claessens et al., 2000). These factors can be explained by the various ethnicities that dominate family ownerships. Haniffa and Cooke (2002) state that cultural factors are imperative because the traditions of a nation are embedded in its society. Therefore, the value instilled can help explain why something happens as it is. Haniffa and Cooke (2002) also classify the multiracial group into two main categories: 1) those who have a cultural affinity indigenous that comes from this region, classified as Malays or Bumiputera (literally means "sons of the soil"), and 2) those whose cultural affiliation is outside the indigenous group, which is classified as nonBumiputera (consisting mainly of Chinese, Indians and others).

Since Malaysia is a developing country with people of various races and backgrounds, ethnic issues can be debated in many fields of studies (CheAhmad et al., 2006). For example, studies by CheAhmad et al. (2006) and Yatim et al. (2006) show that ethnicity plays an important role in determining auditors' choice decision, corporate governance practices and audit fees. Bates (1999) posits that in some countries, the issues of ethnicity have shadowed political systems and have resulted in allegations of prejudice, discrimination, hostility and even violence. They both observe that ethnicity can have an impact on business and economic developments, particularly within East Asian countries. Bates (1999) argues that ethnicity elicits investments and the formation of capital, and thereby enhances growth in developing communities.

As discussed by CheAhmad et al. (2006) and Yatim et al. (2006), corporate ownership in the Malaysian capital market can be clearly identified along ethnic and national lines, specifically Chinese, Bumiputera (Malays) and foreigners. This unique pattern of segmented capital formation is argued to result in differences in business organizations that can, in part, be explained by the ethnicity of the owners. Eichenseher (1995) argues that ethnic divisions across publicly held corporations in Malaysia "can be linked to plausible variations in agency costs". One possible explanation to this variation is due to the differences in business practices.

Although there are three main ethnic groups in Malaysia (primarily Malays, Chinese and Indians) with a presence of various indigenous groups in the states of Sabah and Sarawak, only two major ethnic groups (i.e. Chinese and Malays) control the socioeconomic and political environment of the country (Che Ahmad et al., 2006; Haniffa \& Cooke, 2002). Ethnic Malays (also known as Bumiputeras) are found to control the political administration, while ethnic Chinese have heavily influenced the economic environment (Che Ahmad et al., 2006).

Weidenbaum and Hughes (1996) argue that the Chinese group is the most prevailing entrepreneurial ethnic group in the world. They empower the entrepreneurial exuberance in many nations including Malaysia, Thailand, Indonesia, Vietnam, and progressively in Japan (Ahlstrom, Young, Chan \& Bruton, 2004). Historically, and even at present, business in Malaysia has been dominated by ethnic Chinese groups (known as non-Bumiputera) even though the ethnic Malays group, literally labeled as "son of the soil", account for more than 60 percent of the population. To tackle this continual socio-economic imbalance between ethnic groups (Malays versus Chinese), the government has made efforts to improve it through constructive and productive means. For instance, in the Eleventh Malaysian Plan (2016), the government has effectively created an environment of development based on growth with fair distribution of quality opportunities to stabilize the Chinese entrepreneurship domination in the country. One of the main thrusts of the National Mission is to ensure that Malaysia is capable of sustaining a positive growth impetus. This thrust emphasizes the philosophy of "growth with equity" to resolve socio-economic inequalities between the two ethnic groups of Malays and Chinese (Eleventh Malaysia Plan, 2016).

\section{Family Firms and Leverage}

The theoretical and empirical evidence confirms the existence of interrelation 
between family firms and financial structures. For instance, Margaritis and Psillaki (2010) investigate the relationship between capital structure, ownership structure and firm performance. They find that firms with concentrated ownerships (e.g. family firms) are highly levered and more efficient than firms with dispersed ownerships. This shows that family characters of a firm can also play a significant role in determining the level of debt. Further, Bopaiah (1998) suggests that the unique features of "familiness" value in family firms provide incentives for behaviors that reduce the moral hazard problems perceived by lenders. This implies that family firms can obtain loans more easily than non-family firms. Thus, it confirms the existence of debt level differential between family firms and nonfamily firms with regards to agency problems. In sum, based on the agency theory, family firms are seen to have some motivations to reduce agency costs due to higher shareholding concentration (Anderson \& Reeb, 2003) where there is almost no separation of ownership and control..

The financing behavior of a family firm is a function of its characteristics (Colot \& Croquet, 2009). The debt level in family firms indicates an alternative means of financing which prevents the spread of ownership and loss of family control. Therefore, equity financing becomes the least preferred source of financing among family firms. Moreover, Jensen and Meckling (1976) suggest that family firms experience less severe classical agency problems compared to those in more diffused ownerships, partly due to the personal and familial ties between owners and managers. In line with that, when the ownership structure of firms is highly concentrated and predominantly owned by families, these firms are likely to have greater concerns over family reputation and a greater desire to pass the control of the business onto future generations. As a result, this is likely to influence the financing decisions of the family firms (Maury, 2006; Anderson \& Reeb, 2003).
Companies which are in an affiliated group (e.g. family firms) influence the way they are governed, allowing them to increase capital (Khanna \& Rivkin, 2001). Therefore, leverage decisions in family firms are significantly different from ones outside the affiliated groups (Manos et al., 2007; Chua et al., 2011). This signifies the uniqueness of the ownership structure within the groups that creates its own virtual (or internal) capital resources among the members (e.g. family and friend financing). In addition, theories of market failure and policy distortion of business groups indicate that group-affiliated firms enjoy exceptional access to government and foreign loans (Manos et al., 2007).

Prior studies suggest that family firms comprise of a unique set of investors with undiversified shareholdings, thus reducing agency conflicts between controlling shareholders and management because shareholders (owners) are also managers (Anderson, Mansi \& Reeb, 2003). Consistent with the prediction of the agency theory, when managers are also owners, managers are restrained from engaging in valuedecreasing activities and they are likely to be more risk averse (Ensley and Pearson, 2005). As a result, debt defaults are likely to be lower for family firms, and this leads to lower agency cost of lending, hence lower cost of debt (Anderson, Mansi \& Reeb, 2003; Chua et al., 2011). Bopaiah (1998) also provides evidence that family-owned companies have better credit availability because creditors consider them as having lesser moral hazard problems than nonfamily firms. As such, borrowed funds may not be invested in value-destroying activities that could harm shareholders' wealth. Further, Bopaiah (1998) also reports that family-owned companies generally invest in relatively conservative investment choices, suggesting a lower probability of debt default. As a result, creditors are more confident to lend family firms as compared to their counterparts.

Noorhayati YUSOF ALI and Zuriyati AHMAD, Journal of Southeast Asian Research, DOI: $10.5171 / 2021.122227$ 
The preceding discussion shows that family firms whose ownerships and control are highly concentrated and in the hands of family members are likely to have higher levels of leverage than those firms whose ownerships are widely dispersed. The association between family ownership and leverage can be further explained in the context of the Malaysian corporate landscape, in which the element of ethnicity is involved to help explain, if any, the variations in leverage that may exist among family firms in Malaysia.

\section{Ethnicity and Leverage}

There are three major ethnic groups in the Malaysian society, namely Malays, Chinese and Indians. These ethnic groups are commonly categorized as either Bumiputeras (i.e. majority ethnic Malays and other indigenous population) or nonBumiputeras (i.e. mainly Chinese and Indian descendants). Historically, the Malays and other indigenous populations have been economically lagging behind compared to their non-Bumiputera counterparts. Back in 1970, the government instituted the New Economic Policy (NEP) which primarily intended to reduce the socio-economic gaps particularly between the ethnic Chinese and Malays groups. Among the initiatives included in the NEP programs, were a number of economic and educational privileges accorded to Bumiputeras. The inequalities between Bumiputera and nonBumiputera remain much in the capital ownership and entrepreneurial spirit, although gaps in areas such as educational achievement and occupational attainment have narrowed down (Nagaraj et al., 2007).

Fraser et al. (2006) and Johnson and Milton (2003) suggest that Bumiputera is ethnically-favoured and politically connected. This allegation is proven when the government has made continuous efforts to improve the socio-economic imbalance through constructive and productive means. For instance, in the Eleventh Malaysia Plan (2016), the government provides many privileges to Bumiputera firms such as awarding government contracts, providing greater access to capital resources, broadening opportunities to purchase privatised assets and extending substantial supplementary subsidies. With regards to the access to financial supports, the government and its agencies, such as the Malaysian National Entrepreneur Development Corporation (PUNB) and the Council of Trust for the Bumiputera (MARA), have established various funds in various forms including soft loans, grants, equity financing, venture capital, and financial guarantee schemes. In addition, Bumiputera entrepreneurs are given various business support services such as formal training, marketing channels, provision of business premises and technical guidance. All these privileges posit the government efforts and commitment to inculcate Bumiputera entrepreneurs, if not superior but at least are at par with Chinese entrepreneurs.

Further, the issuance of the Lending Guideline established in 1988 by the National Central Bank (BNM) requires all commercial banks to extend at least 20 percent of the total loans outstanding of the preceded year to the Bumiputera community (Bank Negara Malaysia, 1999). Following this guideline, statistics show that bank loans extended to the Bumiputera community rise steadily and are used to finance a wide range of business activities (Bank Negara Malaysia, 1999, 2009, 2018). Given all these kinds of financial support directed towards helping Bumiputeracontrolled firms, it is predicted that these firms are likely to be highly levered compared to their non-Bumiputera counterparts.

\section{Conclusion}

This study is motivated by the unique corporate structure of Malaysian public listed firms whose ownership is dominated by a few largest shareholders and they are substantially family-owned. As suggested by the agency theory, closely held firms, specifically family firms, can reduce agency problems because owner-managers' interests are likely to be more aligned. The dominant presence of family controlled firms coupled with unique corporate segments, in which corporate boards and equity stake holding are dominated by two 
distinctive ethnic groups, trigger this study to further explore whether family ownership and ethnicity can potentially offer an evidence of capital structure variation that exists in these firms.

This study is unique because it deals with the issue of capital structure determinants outside developed countries. For instance, the element of ethnicity has not been thoroughly investigated in the realms of capital structure in Malaysia, and possibly never in other developed economies. This study offers an alternative explanation for the leverage variations, and provides evidence on the universality of the existing capital structure theory. It enhances the body of knowledge pertaining to debt financing in shaping the capital structure of Malaysian family firms

Evidencing on the previous literature, this study will serve as a platform for authors to conduct empirical studies on this topic in the near future to further strengthen the relevant theories and arguments contained in the field.

\section{Acknowledgment}

The authors of this paper would like to express their deep sense of gratitude to JKIPBSM Universiti Teknologi MARA (UiTM) for approving the grant to fund and make the publication of this paper a reality.

\section{References}

- Abdul Rahman, R. \& Salim, M.R. 2009. Corporate Governance in Malaysia: Theory, Law \& Context. Thomson Sweet \& Maxwell.

- Ahlstrom, D., Young, M.N., Chan, E.S \& Bruton, G.D. (2004). 'Facing Constraints to Growth? Overseas Chinese Entrepreneurs and Traditional Business Practices in East Asia'. Asia Pacific Journal of Management 21(3): 263-285.

- Amran, N.A \& Che Ahmad, A. (2009). 'Family Business, Board Dynamics and Firm Value: Evidence from Malaysia.'
Journal of Financial Reporting \& Accounting 7(1): 53-74.

- $\quad$ Anderson, R.C., Mansi, S.A. \& Reeb, D.M. (2003). 'Founding-Family Ownership and the agency cost of debt.' Journal of Financial Economics 68:263-285.

- Anderson, R.C. \& Reeb, D.M. (2003). 'Founding-Family Ownership, Corporate Diversification, and Firm leverage.' Journal of Law and Economics 46(2):653-684.

- Bank Negara Malaysia. (1999). The Central Bank and the Financial System in Malaysia - A Decade of Change. Kuala Lumpur: Bank Negara Malaysia.

- Bank Negara Malaysia Annual Reports. (2009), [Online], [Retrieved November 20, 2019], http://www.bnm.gov.my/files/publicati on/ar/en/2009/ar2009_book.pdf

- Bank Negara Malaysia Annual Reports. (2018), [Online], [Retrieved October 14, 2019],

https://www.bnm.gov.my/files/publicati on/ar/en/2018/cp01 001 box.pdf

- Bates, R.H., (1999), 'Ethnicity, Capital Formation, and Conflict.' CIAO Working Paper Series [Online], [Retrieved October 2, 2019], http: //www.ciaonet.org/wps/ba ro1/

- $\quad$ Bopaiah, C. (1998). 'Availability of credit to Family Businesses.' Small Business Economics 11: 75-86.

- Brenes, E.R., Madrigal, K. \& Molina, G. (2006). 'Family business structure and succession: Critical topics in Latin American experience.' Journal of Business Review 59: 372-374.

- Carney, M. (2005). 'Corporate governance and competitive advantage in family controlled firms.' Entrepreneurship Theory and Practice 29(3): 249-266.

- CheAhmad, A., Houghton, A. \& Mohamad Yusof, N.Z. (2006). 'The Malaysian market for audit services: ethnicity, multinational companies and auditor choice.' Managerial Auditing Journal 21(7): 702-723.

Noorhayati YUSOF ALI and Zuriyati AHMAD, Journal of Southeast Asian Research, DOI: $10.5171 / 2021.122227$ 
- Chrisman , J.J., Chua, J.H. \& Sharma, P. (2003). 'Current trends and future directions in family business management studies: Toward a theory of family firm.' Coleman White Paper Series [Online], [Retrieved August 12, 2019], http://usasbe.org/knowledge/whitepapers/ch risman2003.pdf

- Chua, J.H., Chrisman, J.J. \& Sharma, P. 1999. Defining the Family Business by behavior. Entrepreneurship: Theory and Practice: 19-39.

- Chua, J.H., Chrisman, J.J., Kellermanns, F. \& Wu, Z. (2011). 'Family involvement and new venture debt financing.' Journal of Business Venturing 26(4): 472-488.

- Claessens, S., Djankov, S. \& Lang, L.P.H. (2000). 'The separation of ownership and control in East Asian corporations.' Journal of Financial Economics 58(1\&2): 81-112.

- Colot, O. \& Croquet, M. (2009). 'Debt of family firms: A comparison based on accounting indicators.' Corporate Ownership \& Control 6(3):53-60.

- Driffield, N., Mahambare, V. \& Pal, S. (2007). 'How does ownership structure affect capital structure and firm value? Recent evidence from East Asia.' Economics of Transition 15(3): 535-573.

- Eichenseher, J.W. (1995). 'Additional factors in audit pricing: new evidence from Malaysia.' Accounting \& Business Review 2(1): 1-26.

- Eleventh Malaysia Plan 2006-2010. Anchoring Growth on People [Online], [Retrieved August 16, 2019], https://policy.asiapacificenergy.org/sites/def ault/files/11th\%20Malaysia\%20plan.pdf

- $\quad$ Ensley, M.D. \& Pearson, A.W. (2005). 'An exploratory comparison of the behavioral dynamics of top management teams in family and nonfamily new ventures: cohesion, conflicts, potency and consensus.' Entrepreneurship: Theory \& Practice 29(3): 267-284.

- Fama, E. \& Jensen, M. 1983. Separation of Ownership and Control. Journal of Law and Economics 26(2):301-325.

- $\quad$ Fan, J.P.H., Titman, S. \& Twite, G. (2012). 'An international comparison of capital structure and debt maturity choices.' Journal of Financial and Quantitative Analysis 47(1): 23-56.
- Fan, J. P.H., Wei, K.C. J. \& Xu, X. (2011). 'Corporate Finance and Governance in Emerging Markets: A Selective Review and an Agenda for Future Research.' Journal of Corporate Finance 17(2): 207214.

- Fraser, D.R., Zhang, H. \& Chek Derashid. (2006). 'Capital structure and political patronage: The case of Malaysia.' Journal of Banking \& Finance 30: 1291-1308.

- Haniffa, R.M. \& Cooke, T.E. (2002). 'Culture, corporate governance and disclosure in Malaysian corporations.' Abacus 38(3): 317-349.

- Jensen, M.C. \& Meckling, W.H. 1976. Theory of the Firm: Managerial Behavior, Agency Costs and Ownership Structure. Journal of financial Economics 3(4): 305360.

- Johnson, S. \& Mitton, T. (2003). 'Cronyism and capital controls: Evidence from Malaysia.' Journal of Financial Economics 67: 351-382.

- Khanna, T. \& Rivkin, J.W. 2001. Estimating the performance effects of business groups in emerging markets. Strategic Management Journal 22: 45-74

- La Porta, R., Lopez-de-Silanes, F. \& Shleifer, A. (1999). 'Corporate Ownership around the World.' The Journal of Finance 54 (2):471-51

- Lean, H., Ting, I., \& Kweh, Q. (2015). 'Ownership Concentration, Family Ownership and Leverage: Evidence from Malaysia.' Malaysian Journal of Economic Studies 52 (2): 117-133

- Majlis Amanah Rakyat (MARA) [Online], [Retrieved September 8, 2019], http://www.mara.gov.my/web/guest/se jarah

- Manos, R., Murinde, V. \& Green, C.J. (2007). 'Leverage and business groups: Evidence from Indian firms.' Journal of Economics and Business 59: 443-465

- Margaritis, D. \& Psillaki, M. 2010. Capital Structure, equity ownership and firm performance. Journal of Banking \& Finance 34: 621-632. 
- $\quad$ Masdiah, A.H, Azizah, A. \& Nur Atiqah, K. (2015). 'Capital Structure and Profitability in Family and Non-Family Firms: Malaysian evidence.' Procedia Economics and Finance 31: 44 - 55

- Maury, B. (2006). 'Family ownership and firm performance: Empirical evidence from Western European corporations.' Journal of Corporate Finance 12: 321341.

- Miller, D. \& Le Breton-Miller, I. (2005). 'Management insights from great and struggling family businesses.' Long Range Planning 38: 517-530.

- Modigliani, F. \& Miller, M.H. (1958). The cost of capital, corporation finance and the Theory of investment. The American Economic Review XLVIII(3):261-297.

- Morck, R. \& Yeung, B. 2003. Agency Problems in Large Family Business Group. Entrepreneurship: Theory \& Practice 27(4): 367-382.

- Nagaraj, S., Hock, L.K., Peng, T.N., Wan, N.C. \& Pala, J. (2007). Counting and Integration: The Experience of Malaysia [Online], [Retrieved September 18, 2019],

- http://eprints.um.edu.my/935/1/S1.4 Shyamala,Lee,Tey,Ng_\%26_Pala.pdf

- Ngui, C.Y.K. (2002). 'Asian Family Businesses: From Riches to Rags?' Malaysian Business 2(27)

- Nwanji, T.I. \& Howell, K.E. 2007. A review of the two main competing models of corporate governance: the shareholdership model versus the stakeholdership model. Corporate Ownership \& Control 5 (1): 9-23.

- Perbadanan Usahawan Nasional Berhad (PUNB) [Online], [Retrieved June 18, 2019],

http://www.punb.com.my/index.php?ch =en_corp

- Sharma, P. (2004). 'An Overview of the Field of Family Business Studies: Current Status and Directions for the Future.' Family Business Review XV11(1): 1-36

- $\quad$ Shleifer, A. \& Vishny, R.W. 1997. A survey of corporate governance. Journal of finance 52(2): 737-783.

- Villalonga, B. \& Amit, R. (2006). 'How do family ownership, control and management affect firm value?' Journal of Financial Economics 80: 385-417.

- Weidenbaum, M. \& Hughes, S. (1996). The Bamboo Network: How Expatriate Chinese Entrepreneurs are Creating a New Economic Superpower in Asia. New York: The Free Press

- Yatim, P., Kent, P. \& Clarkson, P. (2006). 'Governance structures, ethnicity, and audit fees of Malaysian listed firms.' Managerial Auditing Journal 21(7):757782.

Noorhayati YUSOF ALI and Zuriyati AHMAD, Journal of Southeast Asian Research, DOI: $10.5171 / 2021.122227$ 